\title{
COMPARISON OF METHODS FOR THE ASSESSMENT OF FIRE DANGER IN THE CZECH REPUBLIC
}

\author{
František Jurečka1 ${ }^{1}$, Martin Možný ${ }^{1}$, Jan Balek¹, Zdeněk Žalud ${ }^{1}$, \\ Miroslav Trnka ${ }^{1}$ \\ ${ }^{1}$ Global Change Research Institute, Academy of Sciences of the Czech Republic, v.v.i, Bělidla 986/4a, 60300 Brno,
Czech Republic
}

To link to this article: https://doi.org/10.11118/actaun201967051285

Received: 11. 1. 2019, Accepted: 27. 9. 2019

To cite this article: JUREČKA FRANTIŠEK, MOŽNÝ MARTIN, BALEK JAN, ŽALUD ZDENĚK, TRNKA MIROSLAV. 2019. Comparison of Methods for the Assessment of Fire Danger in the Czech Republic. Acta Universitatis Agriculturae et Silviculturae Mendelianae Brunensis, 67(5): 1285-1295.

\begin{abstract}
The performance of fire indices based on weather variables was analyzed with a special focus on the Czech Republic. Three fire weather danger indices that are the basis of fire danger rating systems used in different parts of the world were assessed: the Canadian Fire Weather Index (FWI), Australian Forest Fire Danger Index (FFDI) and Finnish Forest Fire Index (FFI). The performance of the three fire danger indices was investigated at different scales and compared with actual fire events. First, the fire danger indices were analyzed for different land use types during the period 1956-2015. In addition, in the analysis, the three fire danger indices were compared with wildfire events during the period 2001-2015. The fire danger indices were also analyzed for the specific locality of the Bzenec area where a large forest fire event occurred in May 2012. The study also focused on the relationship between fire danger indices and forest fires during 2018 across the area of the Jihomoravský region. Comparison of the index values with real fires showed that the index values corresponded well with the occurrence of forest fires. The analysis of the year 2018 showed that the highest index values were reached on days with the greater fire occurrence. On days with 5 or 7 reported fires per day, the fire danger indices reached values between 3 and 4 .
\end{abstract}

Keywords: fire danger, fire danger rating system, fire danger index, fire event, forest fire, wildfire

\section{INTRODUCTION}

With changing climate conditions, fire danger has started to play an important role in temperate climatic conditions of the Czech Republic. In connection with climate change, the higher occurrence of dry and hot periods is expected in the future. Occurrence of such weather conditions together with windy conditions will most likely cause increasing frequency and severity of wildfires (Jolly et al., 2015). Wildfires generally occur when dry weather, available fuel (e.g., grass, forest stand, and plant litter) and ignition sources meet (Moritz et al., 2005). Particularly during dry spring and summer months, the vegetation is drier and the proportion of both human-caused and natural (i.e., lightning-ignited) vegetation fires increases (Larjavaara, 2005). However, fires are most often human-caused through the careless handling of campfires or cigarettes and grass burning (Tanskanen et al., 2005). To address fire occurrence and reduction in the damage caused by fire, forest fire managers must plan the local distribution of fire resources in advance. Daily fire danger forecasts can be very useful for such situations (Martell et al., 1987). In this paper, the term forest fire danger indicates a forest stand's proneness to fire and is calculated only based on weather conditions. 
To forecast fire danger, different fire danger rating systems have been developed globally. These models produce quantitative or numeric indices of the level of fire potential. They represent various approaches explored for determining fire danger and are designed for different time scales (Vajda et al., 2014).

Since 2006, the Fire Danger Index (FD) has been used for wildfire danger ratings in the Czech Republic (Možný and Bareš, 2013). The FD calculation is based on weather variables: wind speed, soil moisture, air temperature and relative humidity.

The index was successfully validated with data on the frequency of fires in the Czech Republic and Germany during the period 1977-2004. Based on the FD, the Czech Hydrometeorological Institute (CHMI) provides fire danger forecasts for two days and five days in periods that are considered critical for fire ignition (http://portal.chmi.cz). The first three days are calculated from outputs of the Aladin model and the remaining two from the European Center for Medium-Range Weather Forecast (ECMWF) model. The advantage of the approach based on the FD is the use of national weather data from the CHMI. Therefore, fire danger forecasts are more precise and at a higher spatial resolution than forecasts produced by the European Forest Fire Information System (EFFIS), which provides fire danger maps for Europe (http://effis.jrc.ec.europa. $\mathrm{eu}$. The EFFIS adopts the Canadian Fire Weather Index (FWI) system with its inputs, outputs and fire danger ratings. The FWI system is an important part of the Canadian Forest Fire Danger Rating System (CFFDRS) and was initially developed for conditions of boreal forests in Canada (Wotton, 2009). Later, the FWI system has been adapted to a number of countries with different climates to Canada, such as Indonesia and Malaysia (Groot et al., 2006), or countries of the Mediterranean region, i.e., Spain (Padilla and Vega-García, 2011), Portugal (Carvalho et al., 2008), France (Cloppet and Regimbeau, 2010), Serbia (Ratknić et al., 2019) and Greece (Dimitrakopoulos et al., 2011, Karali et al., 2014). Another fire danger rating system is the National Fire Danger Rating System (NFDRS), which is used in the United States (Deeming et al., 1977). The most important outputs of the NFDRS include the energy release component (ERC) and the Keetch-Byram drought index (KBDI). To forecast the influence of weather on fire behavior, the Forest Fire Danger Index (FFDI) is widely used in Australia (Dowdy et al., 2009). FFDI forecasts are routinely issued for the use by fire authorities (http://www.bom.gov.au). Another system that estimates the fire danger is the Forest Fire Index (FFI) (Heikinhemo et al., 1998). The FFI system has been used in Finland since 1996. The Finnish Meteorological Institute (FMI) issues daily fire danger forecasts across Finland on its website (http://en.ilmatieteenlaitos.fi).
The main objective of the paper is to investigate the ability of three commonly used fire danger indices to predict fire danger for the territory of the Czech Republic representing temperate climate of Central Europe. Another objective is to test the ability of indices to detect fire weather conditions at different levels (the whole country, the Jihomoravský region, the specific forest site in the Bzenec area) while their performance was compared with actual fire events.

\section{MATERIALS AND METHODS}

\section{Methods Used for Fire Danger Assessment}

Various fire danger rating systems have been developed in different parts of the world where the forecasting of fire danger is crucial. Features of the fire danger rating systems analyzed in this study are briefly described in the text below.

\section{Fire Weather Index (FWI) System}

The FWI system was initially developed for conditions of boreal forests in Canada and it provided means of evaluating the severity of fire weather conditions in a standardized forest type (Wotton, 2009). Today, it is one of the most widely used fire danger rating systems, specifically in Europe (including the Mediterranean region) and North America. The FWI system is the part of the Canadian Forest Fire Danger Rating System (CFFDRS) and provides a rating of the fuel moisture content in important fuel layers and several outputs describing fire behavior (Wotton, 2009).

FWI outputs include three moisture codes that track the moisture content at different levels of the forest floor. These three moisture codes are key components of the FWI system because they enable the ability to track the moisture content in three layers of the forest floor and play an essential role in fire ignition, its spread and suppression. The moisture codes are the basis for three fire behavior codes that represent the relative rating of fire behavior potential. Altogether, there are six outputs of the FWI system: Fine Fuel Moisture Code (FFMC), Duff Moisture Code (DMC), Drought Code (DC), Initial Spread Index (ISI), Buildup Index (BUI) and FWI (Wotton, 2009).

FWI is the final index of the FWI system determined by combining ISI and BUI. The FWI is a unitless indicator of the expected fire intensity and is valuable, specifically in situations in which a single indicator of the general fire potential is needed (Wotton, 2009).

The FWI can be expressed at different scales. Therefore, the FWI can be calculated as a B-scale, D-scale, I-scale or S-scale index depending on the normal limits of the index. Accordingly, the FWI scale was derived from a graph of the fire intensities of experimental fires in Petawawa 
(Ontario, Canada). The currently used S-scale FWI was described by Van Wagner (1974) as follows:

$\ln S=2.72 \times(0.434 \times \ln B)^{0.647}$

where:

S .......................S-scale FWI and

B........................ B-scale FWI.

The B-scale FWI is defined (Van Wagner 1974) as follows:

$B=0.1 \times R \times f(D)$

where:

R........................ Initial Spread Index and

$\mathrm{f}(\mathrm{D})$.................... Duff moisture function.

The equation for the S-scale FWI has one restriction. When $\mathrm{B}$ is less than 1 , its logarithm is negative and cannot be taken to the fractional power. In these cases, $\mathrm{S}$ is set equal to B. It should also be noted that this FWI equation never yields a true zero. For reporting purposes, the FWI is rounded to the nearest whole number. The latter means that when the FWI value is less than 0.5, the index is reported as 0 (Van Wagner, 1974).

\section{Forest Fire Danger Index (FFDI)}

The FFDI (McArthur, 1967) is widely used in Australia for forecasting the influence of weather on fire behavior. The FFDI is a key tool for assessing fire danger in Australia (Dowdy et al., 2009). Fire managers and authorities in Australia use regular FFDI forecasts published by the Australian Bureau of Meteorology.

The formulation of the FFDI (e.g., Noble et al., 1980) is based on weather parameters as well as on the Drought Factor (DF) (Dowdy et al., 2009) and represents the fuel availability in the forest environment. The DF is between 0 and 10 , representing the influence of recent temperatures and rainfall events on the fuel availability (Griffiths, 1998). In Australia, the DF is commonly calculated as either the Keetch-Byram drought index (KBDI) (Keetch and Byram, 1968) or the Soil Dryness Index (SDI) (Mount, 1972) depending on the agreed practice in each state.

The equation of the FFDI (e.g., Noble et al., 1980) is as follows:

$F F D I=2 e^{(-0.45+0.987 \ln (D F)-0.0345 R H+0.0338 T+0.0234 u)}$

where:

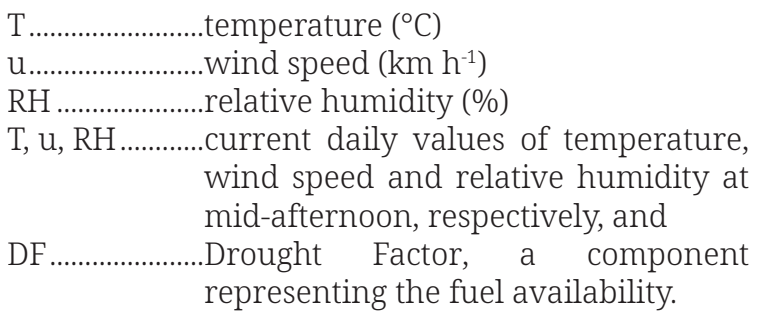
representing the fuel availability.
The FFDI is calculated at point locations in a network across Australia. The necessary observations for both the calculation and forecast verification must be available at these point locations. Although the FFDI is calculated with the aid of point data, determination of the FFDI outputs (e.g., Fire Weather Warning) is designed for regions and is area-based (Finkele et al., 2006).

The FFDI system uses a rating from 0 to 50 (and beyond), where 0 represents low danger and 50 and greater indicate extreme fire danger. The FFDI uses different thresholds for Tasmania compared to mainland Australia because the considerable fire activity occurs at FFDI levels lower than 50 (Dowdy et al., 2009).

\section{Finnish Fire Index (FFI)}

Another index used in Europe for forecasting fire danger is the FFI. The FFI system is the basis for evaluating forest fire hazards in Finland. The Finnish Meteorological Institute (FMI) operationally monitors conditions favorable for forest fire potential. As part of the fire danger warning strategy, the FMI issues a daily map of fire danger in Finland on its website that is available from early May to September or early October. The fire weather forecasts are specific for each province of Finland and are provided for the current date and subsequent four days (http://en.ilmatieteenlaitos. fi). The value of the FFI is essentially the estimated moisture content of a surface layer expressed as (Heikinhemo et al., 1998):

$D W=E_{p o t} \times D E+P_{i}$

where:

DW $\left(\mathrm{m}^{3} \mathrm{~m}^{-3}\right)$....change in the volumetric moisture content of the total surface layer

$E_{\text {pot }}(\mathrm{mm})$..........potential evaporation (ET), for current operational applications, potential ET is calculated from the PenmanMonteith equation (e.g., Monteith, 1981)

DE....................the drying efficiency and

$\mathrm{P}_{\mathrm{i}}(\mathrm{mm})$.............amount of water remaining in the surface layer.

The initial equation can also be expressed as (described by Vajda et al., 2014):

$D W=E_{p o t} \times \frac{0.757}{1+e^{\left(2.74-16.67 \times\left(W_{v o t}-0.1\right)\right)}}+5.612 \times\left(1-e^{(-P / 5.612)}\right)$

where:

$\mathrm{E}_{\mathrm{pot}}(\mathrm{mm})$..........potential evaporation

$\mathrm{W}_{\text {vol }}\left(\mathrm{m}^{3} \mathrm{~m}^{-3}\right)$..volumetric moisture of the surface layer and

P (mm).............precipitation.

The FFI calculation is based on data from weather stations across Finland together with data from the weather radar network. A numerical weather 
prediction model (NWP) is an additional input needed for the FFI calculation (Vajda et al., 2014).

The NWP model evaluates the surface moisture of half-open treeless terrains. The model assumes that open areas will dry faster than areas with intensive forest stands and therefore more likely represent a flammable type of terrain. The NWP model calculates the humus content as part of surface moisture for layers with thicknesses of 3 and $6 \mathrm{~cm}$. Only the thicker layer of $6 \mathrm{~cm}$ is used for the FFI calculation (http://en.ilmatieteenlaitos.fi).

FFI values range from 1 to 6 , where the lower numbers refer to lower fire danger and vice versa. Fire danger is considered to exist with FFI $\geq 4$ (Mäkelä, 2015).

\section{Fire Weather Danger Inputs}

Daily meteorological data from the network of climatological sites and rain gauges across the Czech Republic have been used as inputs for the calculation of the FWI, FFDI and FFI. Daily weather inputs were then interpolated to $500 \mathrm{~m}$ grids.

The calculation of the FWI incorporates weather observations at 13:00 local standard time. To accommodate this requirement, daily maximum air temperature and minimum relative humidity were used. Another weather input for the FWI is maximum daily wind speed. However, this weather parameter is available only from a limited number of sites (approximately 70) with large gaps and inhomogeneities (e.g. Brázdil et al., 2017). Therefore, the relationship between mean daily wind speed and maximum wind shear was developed and applied. In case of the FFDI, wind speed at 14:00 was used as required. All weather inputs needed for the index calculation can be found in Tab. I.

For all three indices (FWI, FFDI and FFI), the soil moisture content was obtained from the Czech national drought monitoring system using daily estimations from the SoilClim model (Hlavinka et al., 2011). SoilClim is a water balance-based model that uses basic meteorological inputs measured in situ, as well as information about the soil and land cover. SoilClim is routinely used as a tool for drought monitoring in the Czech Republic. The model provides estimates of soil moisture content in two layers of the soil profile: from the ground surface to $0.4 \mathrm{~m}$ and from 0.4 to $1 \mathrm{~m}$ depth (www.intersucho.cz).

\section{Other Inputs}

In addition to the weather parameters, other significant characteristics were involved in the fire danger index calculation.

To calculate the FFI, potential evapotranspiration (ET) is needed. For the current operational application used in Finland, the potential ET is calculated from the Penman-Monteith equation (e.g., Monteith, 1981). Input parameters needed for calculation of potential ET include air temperature and relative humidity, surface radiation balance and wind speed. Radiation balance components are currently calculated using cloud data from a numerical weather prediction model (Vajda et al., 2014). For the area of the Czech Republic, potential ET is calculated using the SoilClim model.

In case of the Australian FFDI, the DF is involved in the index equation. The DF is commonly calculated as either the KBDI or the SDI. In both the KBDI and the SDI, the water balance is expressed as the soil moisture deficit (SMD). The SMD (mm) represents the amount of water necessary to elevate the soil moisture content to the field capacity, i.e., the amount of water that the soil can hold in its capillaries while gravity works (Finkele et al., 2006). The effective rainfall and ET are involved in the SMD equation. For this study, ET is calculated as actual ET according to the Penman-Monteith method (Allen et al., 1998) implemented within the SoilClim water balance and soil moisture model (Hlavinka et al., 2011).

All three applied fire danger forecast methods (FWI, FFDI and FFI) provide a numerical index that increases with fire danger and that is expressed as a fire danger scale. The Canadian FWI uses 5 classes from very low to extreme (from 0 to 29 and beyond). The Australian FFDI uses 5 classes from low to extreme (0 to 50 and beyond). The Finnish FFI has 6 classes from very wet to very dry moisture conditions (from 1 to and 6). In this study, the common scale from 1 to 5 was used, where 1 represents low fire danger and 5 indicates extreme danger.

I: Input weather parameters needed for the calculation of fire danger indices.

\begin{tabular}{lccc}
\hline & FWI & FFDI & FFI \\
\hline Air temperature & $\mathrm{x}$ & $\mathrm{x}$ & $\mathrm{x}$ \\
Relative humidity & $\mathrm{x}$ & $\mathrm{x}$ & $\mathrm{x}$ \\
Wind speed & $\mathrm{x}$ & $\mathrm{x}$ & $\mathrm{x}$ \\
Precipitation & $\mathrm{x}$ & $\mathrm{x}$ & $\mathrm{x}$ \\
Radiance balance & & & $\mathrm{x}$ \\
\hline
\end{tabular}

\section{Different Levels of Index Comparison}

The performance of the FWI, FFDI and FFI indices was compared at different spatial and temporal levels. First, the performance of the indices over the entire area of the Czech Republic was analyzed. The analysis was performed for the part of the growing season when vegetation is most prone to fire ignition. This period was then divided into two parts: April to June and July to August. The fire danger intensity was assessed for the period 19562015, while four different land use types were considered.

One of possibilities for evaluating the performance of the fire danger indices was to relate 
their values to actual fire events, even though this approach has certain limitations. Therefore, as a second step, analysis of three fire danger indices versus wildfire events for the period 2001-2015 was performed. The analysis was undertaken for the area of the Czech Republic focusing on the part of the growing season from April to September. The total number of wildfires during the analyzed period was retrieved from the Fire Rescue Service of the Czech Republic (http://www.hzscr.cz).

Third, the performance of the FWI, FFDI and FFI was analyzed specifically for the Bzenec area in the Jihomoravský kraj (the southeastern part of the Czech Republic), where a fire event occurred in May 2012. The actual fire event occurred in a pine forest during the period of $24^{\text {th }}-30^{\text {th }}$ May 2012 and was the largest forest fire event recorded in recent years in the Czech Republic; 174 hectares of forest burned.

Moreover, special attention was paid to the year 2018 with its warm and dry spring and summer in comparison with long-term weather characteristics (http://portal.chmi.cz). Three fire danger indices were compared with forest fire events that occurred during the period lasting from January to the end of September. Data on forest fire occurrence were obtained from the Fire Rescue Service. Indices and fire events were analyzed across the Jihomoravský region, which is considered the warmest and driest region of the Czech Republic (Trnka et al., 2016).

\section{RESULTS AND DISCUSSION}

Fig. 1 shows the order of years according to the percentage of the area that was under high risk of fire based on the FWI, FFDI and FFI during the period 1956-2015. The order was determined for four different land use types across the Czech Republic (arable land, grassland, deciduous trees and coniferous trees) during two parts of the growing season - from April to June and from July to August. For the period of April-June, we marked the years 1976, 2000, 2003 and 2007 as clearly standing out for all land use types; it was observed that they were affected by high risk weather. For the period July-August, the most significant years with high risk weather were 1971, 1990, 1992, 1994, 2003 and 2015. According to the fire weather risk, the most exceptional year for all land use types was 2015. Particularly for the period July-August, FWI and FFDI often marked the same years that were the most significant regarding the area under high risk. The area under high risk of fire was much larger during the period July-August than that during the April-June period, with the highest percentage calculated for arable land.

To add complexity to the study, a comparison of three fire danger indices and wildfire events in the Czech Republic was conducted. The comparison was performed for the period 2001-2015 focusing on the part of the year from April to September
(Fig. 2). Fig. 2a shows the evolution of the fire danger indices with the number of wildfire events occurring during the period 2001-2015. The areal means of three indices (expressed as z-score) corresponded well with occurrence of fire events. All three indices performed similarly, even though at different magnitude, particularly the FWI often resulted in higher values than the FFDI and FFI. All three indices corresponded well to high occurrence of fire events in 2003, 2007, 2011, 2012 and 2015, exhibiting the highest values for 2003 and 2015 when drought spells and intensive heatwaves appeared in the Czech Republic and surrounding countries. These findings correspond well with the study of Možný and Bareš (2013) that evaluated fire danger by the Fire Danger Index (FD). The range of FD values is from 1 to 5 , where 1 indicates very low danger and 5 represents very high danger. The duration of fire danger during the period 1951-2013 for the area of the Czech Republic was analyzed. The highest number of days with high fire danger (FD $\geq 4$ ) was in years 2012 (102 days), 1976 (95), 2007 (81), 1973 (78), 2011 (76), 1992 (71) and 2003 (68).

Fig. $2 \mathrm{~b}-\mathrm{d}$ show the relationships between the mean value of the fire danger indices and the number of wildfires during the period AprilSeptember for 2001-2015. The scatterplots of the FWI and FFDI had values of $\mathrm{R}^{2}=0.77$ and that of the FFI had a value of $\mathrm{R}^{2}=0.59$, all are statistically significant at the 0.05 level $(\mathrm{p}<0.05)$. Karali et al. (2014) investigated the FWI in meteorological conditions of Greece. The FWI was evaluated by comparison with recorded fire events during the period 1983-1997. The FWI was compared with the mean number of fires per unit area (based on the location of meteorological stations) and confirmed to be able to predict fire occurrence with $\mathrm{R}^{2}$ reaching values from 0.71 to 0.92 .

Fig. 3 focuses on the performance of fire danger indices (FWI, FFDI and FFI) in the Bzenec area that was affected by the forest fire event in 2012. The evaluation was conducted for the period $1^{\text {st }}$ March - $31^{\text {st }}$ July 2012, or DOY (day of year) 61-213. The actual fire event occurred during the period 24th $-30^{\text {th }}$ May 2012 (DOY 145-151). The period of the fire event is represented in Fig. 3 by the green rectangle. From $20^{\text {th }}$ (DOY 141) to $26^{\text {th }}$ May (DOY 147), the indices exceeded a value of 4 for nearly all days. This period lasted for the FFI until $27^{\text {th }}$ May (DOY 148). Then, until $30^{\text {th }}$ May (DOY 151), indices did not reach higher values than 3; only the FWI reached a value of 4 but only for one day (30 ${ }^{\text {th }}$ May, DOY 151). These results fit well with the analysis of fire danger based on the FD that was published in the book Droughts in the Czech Lands: Past, Present and Future (Brázdil et al., 2015). The analysis illustrates that there was high fire danger $(F D \geq 4)$ in the Bzenec area from $20^{\text {th }}$ (DOY 141) to $28^{\text {th }}$ May (DOY 149). 

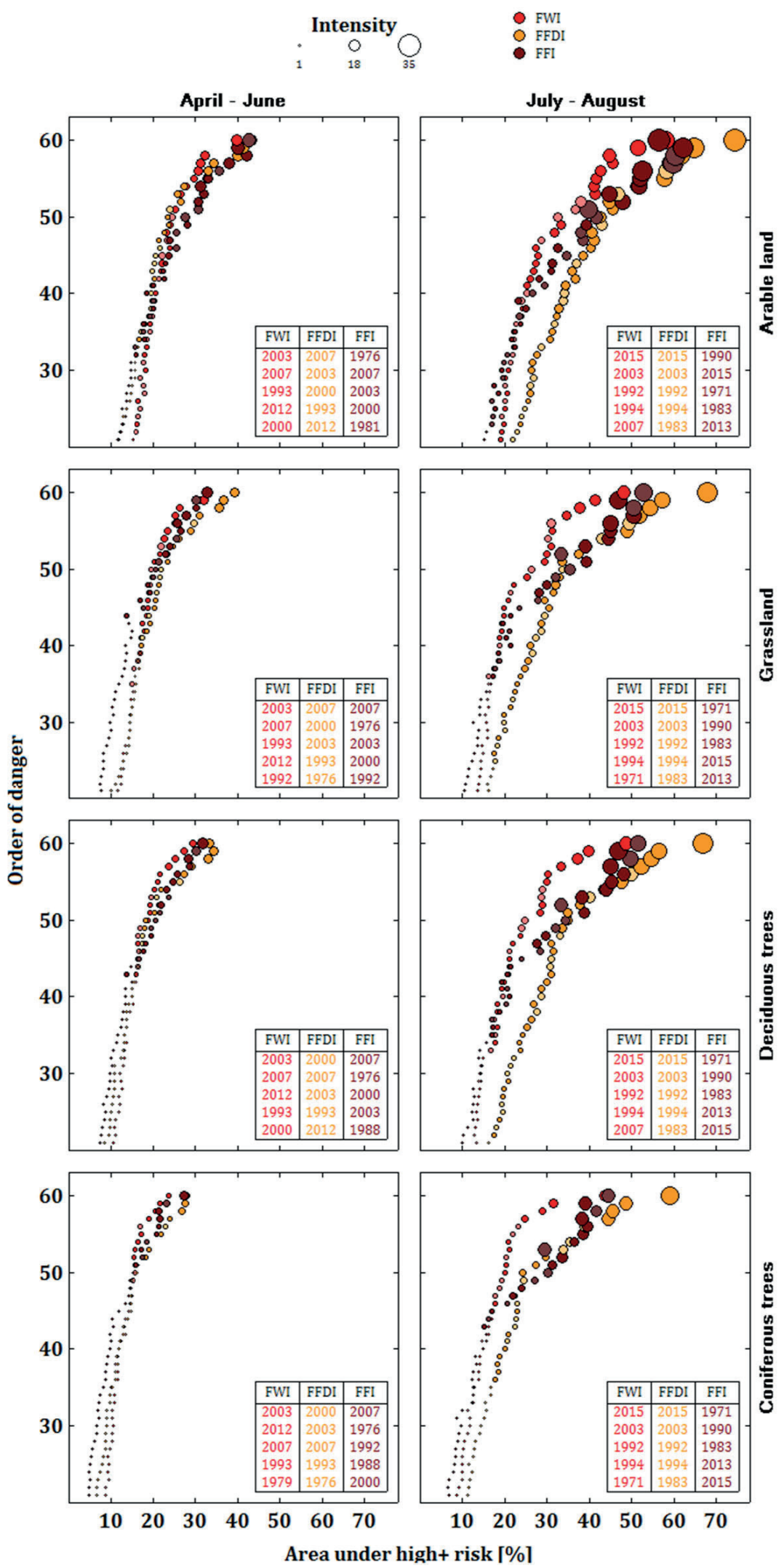

1: Order of years according to the area under high risk of fire based on the FWI, FFDI and FFI. The ordering is performed across the territory of the Czech Republic during the period 1956-2015. The table in the lower right corner indicates top five years according to the area affected by fire conducive weather. The territory is divided according to four main land use types. 

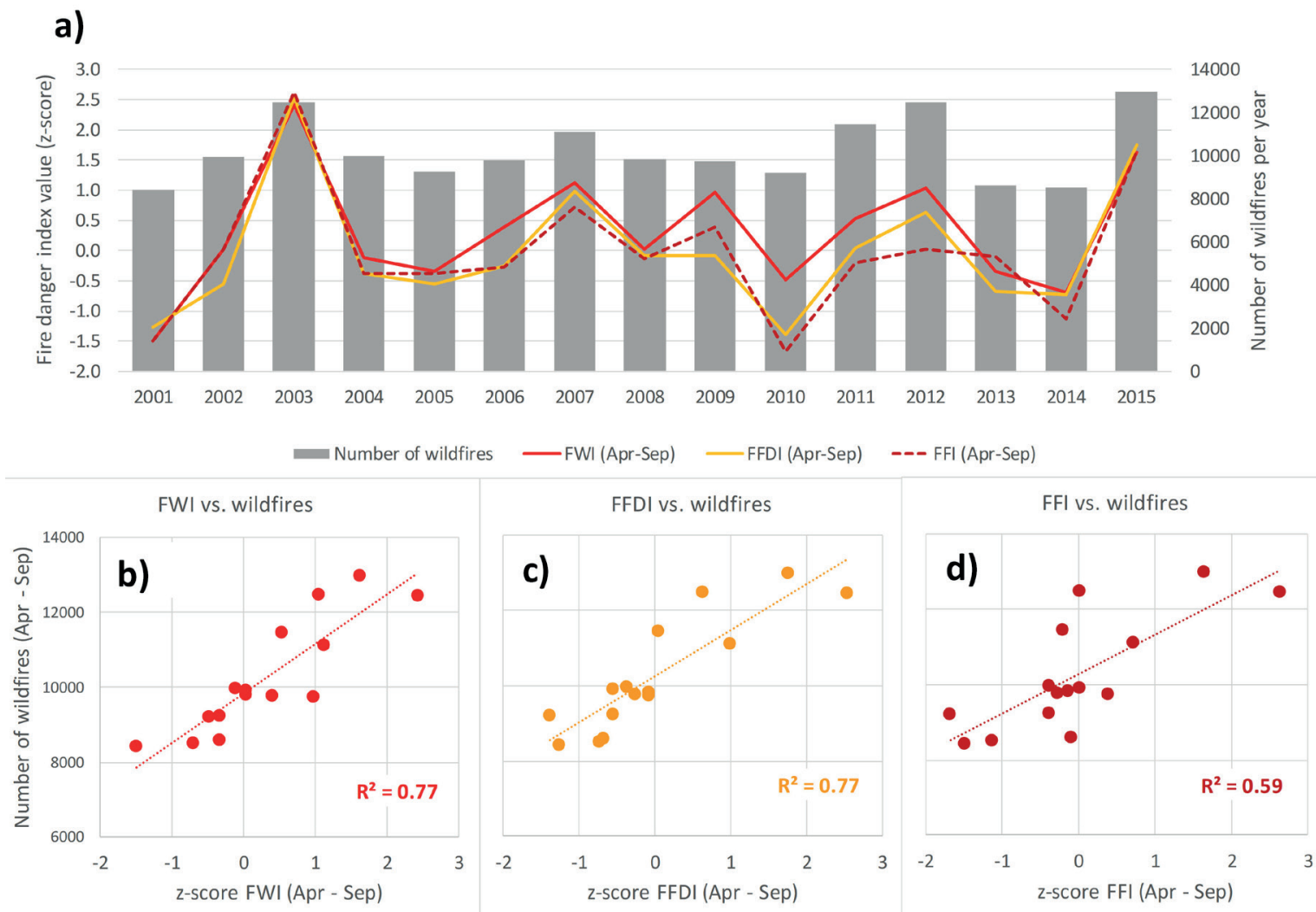

2: (a) Fluctuations in the total number of wildfires across the Czech Republic and the areal means of fire danger indices (expressed as z-score) in April-September during 2001-2015; 2 (b-d) Relationships between the seasonal sum of fire danger indices (expressed as z-score) and the total number of wildfires across the Czech Republic in April-September during 2001-2015.
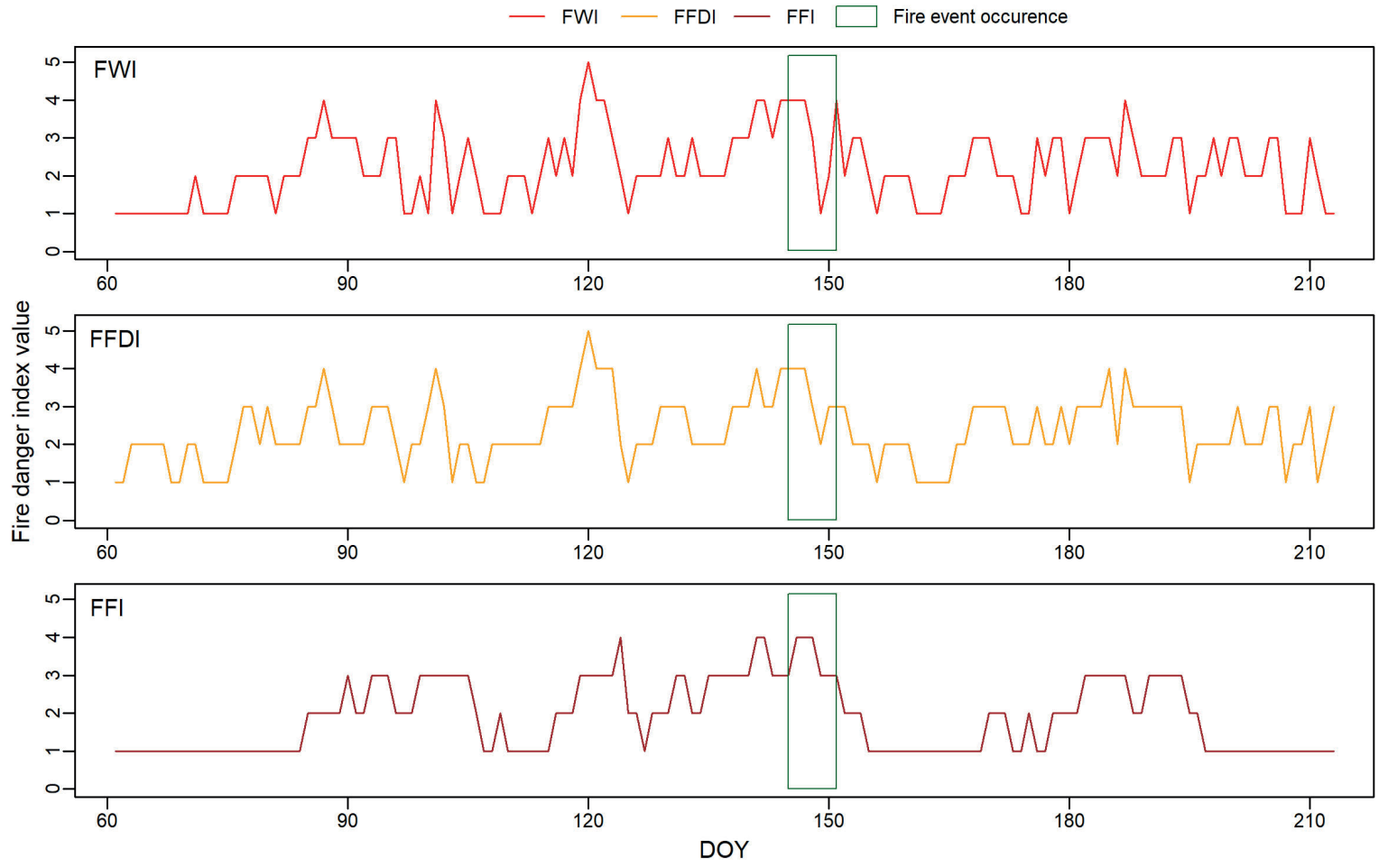

3: Performance of the fire danger indices (FWI, FFDI and FFI) in the Bzenec area where a fire event in a pine forest occurred in May 2012. The comparison was conducted for the period 15t March - 31 st July 2012 (DOY 61-213). The green rectangle represents the period of fire event occurrence in Bzenec (DOY 145-151). 
The specific focus was on the year 2018 and an area in the Jihomoravský region. In Fig. 4, three fire danger indices are compared with forest fire events occurring from January to September of the year 2018 (DOY 1-263). At the beginning of the year, forest fires occurred rather rarely, but from the end of February (from $21^{\text {st }}$ February, or DOY 52), the fire frequency increased. In particular, the FFDI was able to capture this period quite well. From the beginning of April (starting $8^{\text {th }}$ April, or DOY 98), the fire frequency increased even more - often with 2 or more fires on any particular day. A large number of forest fires occurred in particular at the beginning of April. Then, at the end of June, a period with more frequent fire events started and lasted till the beginning of September. Starting on $2^{\text {nd }}$ July (DOY 183), there was a forest fire event nearly every day. This period lasted until 29 ${ }^{\text {th }}$ August (DOY 241). The largest number of forest fires was recorded on $8^{\text {th }}$ April, 21 $1^{\text {st }}$ June and 23 $3^{\text {rd }}$ August (DOY 98, 172 and 235, respectively) when 7 fire events occurred in the Jihomoravský region.

The occurrence of forest fires during this period corresponded well with values of the fire danger indices, particularly on days when more forest fires occurred. The correspondence of fire events with indices was most significant on days with 5 and more fires per day. On these days, the fire danger indices often reached values between 3 and 4 . The FWI and FFDI often showed similar performance, while the FFI performed differently in many cases and reached relatively lower values. The exception was $23^{\text {rd }}$ August (DOY 235), when 7 fire events were recorded; the FFI value was 4.5, while the FWI and FFDI were 3.9 and 4, respectively. The different performance of the FFI and FWI partially corresponds with results of Vajda et al. (2014), especially in case of the northern Finland. Vajda et al. compared the performance of the FFI and FWI with the regional fire activity in Finland during the period 2005-2010. In this study, big differences between the southern and northern Finland were found. The FFI and FWI performed similarly in the central and southern Finland but in the north, the amount of cases with high fire danger performed by the FWI was almost double compared to the FFI.

Comparison of the fire danger indices with real fire events seems to be a useful way to calibrate different tools of fire danger forecasting, even though the approach has certain weak points and limitations. The largest weak point and limitation is the fact that the large percentage of fires is humancaused and only a small portion of fires occur naturally, e.g., by lightening (as mentioned, e.g., by Vajda et al., 2014). Therefore, comparison of indices with fire events occurring on particular days can be biased and inaccurate, particularly in areas close to cities, human settlements and recreation areas.

Because an increase in the number of fire danger is very probable under future climate conditions, it is essential to continue improving the existing tools for the forecasting of fire danger.
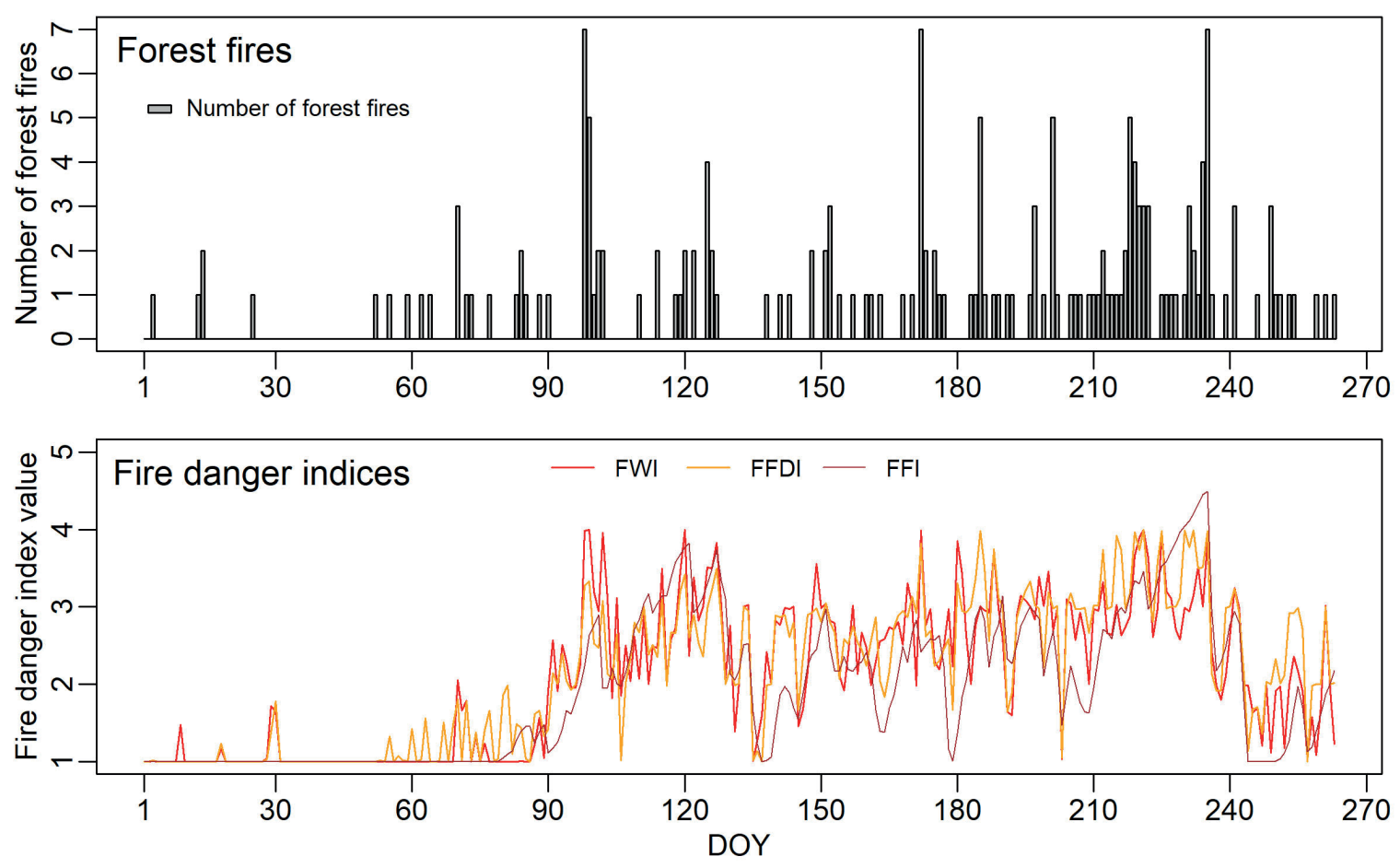

4: The occurrence of forest fire events in the Jihomoravsky region and areal means of the fire danger indices (FWI, FFDI and FFI) for the period $1^{\text {st }}$ January - 20 $0^{\text {th }}$ September 2018 (DOY 1-263) 
It is necessary to calibrate these tools to local conditions to preserve a proper degree of accuracy. However, the utilization of various methods for particular areas and times can be challenging in many ways. One challenge is that certain methods can require meteorological elements that are not usually measured at meteorological stations. As an example, we discuss the Finnish FFI. Components of radiation balance are required in the calculation of the potential ET that is the part of the FFI equation. However, these inputs are not always easily available from routine weather observations.

In this study, special attention was paid to the fire weather conditions of 2018 in the Jihomoravský region. This region was chosen due to its climatic characteristics, which are more prone to fire ignition in comparison to those of other regions in the Czech Republic. Although comparison between the forest fire events and indices showed consistent results, more detailed research is needed to fully understand the mutual relationships. In this study, the fire danger indices were compared only with forest fires and not with all types of fires occurring in the landscape. Comparison of the index values with all wildfires could help us evaluate this issue in a new light because the Jihomoravský region is typically an agricultural region with a low percentage of forested areas. However, these data were not available during the study.

\section{CONCLUSION}

In this study, the performance of three fire danger indices derived from weather variables was evaluated. All three indices were able to classify the fire weather in climatic conditions of the Czech Republic according to their disposition to fire ignition.

Complexity of the study lies in the analysis of three fire danger indices at different spatial and temporal levels. First, indices were compared over the entire area of the Czech Republic while four land use types were considered. The approach of comparing three indices with fire events recorded by the Fire Rescue Service was then investigated. The approach was tested for the whole country over the period 2001-2015, as well as for the Bzenec area located in the southeastern part of the Czech Republic. This area was chosen due to the fact that a large forest fire event occurred there in May 2012. The focus was then shifted to the area of the Jihomoravský region and the year 2018. This year was characteristic by its warm and dry spring and summer in comparison with long-term weather characteristics.

Even though many other factors related to human activities need to be taken into account, comparison of the fire danger indices with actual fire events appeared to be promising and resulted in reasonable outputs. All indices analyzed in the study were able to detect high fire danger during periods with a large number of fires or years with dry and warm weather favorable for fire ignition.

When values of the three indices were compared with forest fires in 2018 for the Jihomoravský region, the values agreed well on days with the larger number of fire events, even though they performed at different magnitudes. On days with the higher frequency of fires, the fire danger indices often reached values between 3 and 4. The FWI and FFDI often exhibited similar performance, while the FFI performed in many cases differently and resulted in different, mostly lower values.

Similar results were obtained when the fire danger indices were compared with all wildfires in the Czech Republic during the period 2001-2015. All indices reached similar values, while the FWI in some years performed differently, with higher values. All three indices reached highest values in years 2003 and 2015 that were very hot and dry in Central Europe. In this case and in case of the analysis of areas with different land use (during the period 1956-2015), all three indices were able to detect dry and warm years with high occurrence of fire events.

Although the overall comparison between the fire danger indices and fire events did not consider preventive measurements undertaken by the Fire Rescue Service and other organizations, investigated indices can still be used as valuable indicators for defining periods with weather conditions favorable for fire ignition. Although the area of Central Europe is not currently considered as most prone to fire in comparison with Mediterranean area, this situation will most likely change and such periods will be more common in the future. Therefore, methods that are able to indicate potential fire danger will play an important role.

\section{Acknowledgements}

This study was supported by SustES - Adaptation strategies for sustainable ecosystem services and food security under adverse environmental conditions (CZ.02.1.01/0.0/0.0/16_019/0000797). 


\section{REFERENCES}

ALLEN, R. G., PEREIRA, L. S., RAES, D. and SMITH, M. 1998. FAO Irrigation and Drainage Paper Crop Crop evapotranspiration - Guidelines for computing crop water requirements. FAO Irrigation and drainage paper 56. Rome, Italy: FAO.

BRADSHAW, L. S., DEEMING, J. E., BURGAN, R. E. and COHEN, J. D. 1977. The 1978 National firedanger rating system: technical documentation. General Technical Report INT-39. Ogden, UT: U.S. Department of Agriculture, Forest Service.

BRÁZDIL, R., TRNKA, M. et al. 2015. Droughts in the Czech Lands: Past, Present and Future. Brno: Global Change Research Institute CAS.

BRÁZDIL, R., ZAHRADNÍČEK, P., ŘEZNÍČKOVÁ, L., TOLASZ, R., ŠTĚPÁNEK, P. and DOBROVOLNÝ, P. 2017. Spatial and temporal variability of mean daily wind speeds in the Czech Republic, 19612015. Climate Research, 72(3): 197-216.

CARVALHO, A., FLANNIGAN, M. D., LOGAN, K., MIRANDA, A. I., BORREGO, C. 2008. Fire activity in Portugal and its relationship to weather and the Canadian Fire Weather Index System. International Journal of Wildland Fire, 17(3): 328-338.

CLOPPET, E. and REGIMBEAU, M. 2010. Fire Weather Index: from high resolution climatology to climate change impact study. In: 10 th European Conference on Applications of Meteorology (ECAM). Zürich, 13-17 September 2010.

COHEN, J. D. and DEEMING, J. E. 1985. The National Fire-Danger Rating System: basic equations. General Technical Report PSW-82. Berkeley, CA: U.S. Department of Agriculture, Forest Service.

DE GROOT, W. J., FIELD, R. D., BRADY, M. A., ROSWINTIARTI, O. and MOHAMAD, M. 2006. Development of the Indonesian and Malaysian Fire Danger Rating Systems. Mitigation and Adaptation Strategies for Global Change, 12(1): 165-180.

DIMITRAKOPOULOS, A., BEMMERZOUK, A. and MITSOPOULOS, I. D. 2011. Evaluation of the Canadian fire weather index system in an eastern Mediterranean environment. Meteorological Applications, 18(1): 83-93.

DOWDY, A. J., MILLS, G. A., FINKELE, K. and DE GROOT, W. 2009. Australian fire weather as represented by the McArthur Forest Fire Danger Index and the Canadian Forest Fire Weather Index. CAWCR Technical Report No. 10. Centre for Australian Weather and Climate Research.

FINKELE, K., MILLS, G. A., BEARD, G. and JONES, D. A. 2006. National gridded drought factors and comparison of two soil moisture deficit formulations used in prediction of Forest Fire Danger Index in Australia. Australian Meteorological Magazine, 55: 183-197.

GRIFFITHS, D. 1998. Improved Formulae for the McArthur Forest Fire Danger Meter. Australia: Bureau of Meteorology.

HEIKINHEMO M., VENÄLÄINEN, A. and TOURULA T. 1998. A soil moisture index for the assessment of forest fire risk in the boreal zone. In: Proceedings of the International Symposium on Applied Agrometeorology and Agroclimatology. Volos, Greece, pp. 549-555.

HLAVINKA, P., TRNKA, M., BALEK, J., SEMERÁDOVÁ, D., HAYES, M., SVOBODA, M. et al. 2011. Development and evaluation of the SoilClim model for water balance and soil climate estimates. Agricultural Water Management, 98(8): 1249-1261.

JOLLY, W. M., COCHRANE, M. A., FREEBORN, P. H., HOLDEN, Z. A., BROWN, T. J., WILLIAMSON, G. J., BOWMAN, D. M. 2015. Climate-induced variations in global wildfire danger from 1979 to 2013. Nature Communications, 6: 7537.

KARALI, A., HATZAKI, M., GIANNAKOPOULOS, C., ROUSSOS, A., XANTHOPOULOS, G. and TENENTES, V. 2014. Sensitivity and evaluation of current fire risk and future projections due to climate change: the case study of Greece. Natural Hazards and Earth System Sciences, 14(1): 143-153.

KEETCH, J. J. and BYRAM, G. M. 1968. A Drought Index for Forest Fire Control. Research Paper E-38. Asheville, NC: U.S. Department of Agriculture, Forest Service.

LARJAVAARA, M. 2005. Climate and forest fires in Finland - influence of lightning-caused ignitions and fuel moisture. Dissertationes Forestales 5. Helsinki: University of Helsinki.

MÄKELÄ, H. M. 2015. Estimates of past and future forest fire danger in Finland from a climatological viewpoint. Finnish Meteorological Institute Contributions No. 112. Helsinki: Finnish Meteorological Institute.

MARTELL, D. L., OTUKOL, S. and STOCKS, B. J. 1987. A logistic model for predicting daily peoplecaused forest fire occurrence in Ontario. Canadian Journal of Forest Research, 17(5): 394-401.

McARTHUR, A. G. 1967. Fire Behaviour in Eucalypt Forests. Leaflet 107. Canberra: Department of National Development Forestry and Timber Bureau.

MONTEITH, J. 1981. Evaporation and surface temperature. Quarterly Journal of the Royal Meteorological Society, 107(451): 1-27. 
MORITZ, M. A., MORAIS, M. E., SUMMERELL, L. A., CARLSON, J. M. and DOYLE, J. 2005. Wildfires, complexity, and highly optimized tolerance. Proceedings of the National Academy of Sciences of the United States of America, 102(50): 17912-17917

MOUNT, A. B. 1972. The Derivation and Testing of a Soil Dryness Index: Using Run-off Data. Tasmania: Tasmania Forestry Commission.

MOŽNÝ, M. and BAREŠ, D. 2013. Czech Fire-Danger Rating System. The Integrated Warning Service System. Methodological Guideline No. 3/2013. Prague: Czech Hydrometeorological Institute.

NOBLE I. R., GILL A. M. and BARY, G. A. V. 1980. McArthur's fire-danger meters expressed as equations. Australian Journal of Ecology, 5(2): 201-203.

PADILLA, M. and VEGA-GARCÍA, C. 2011. On the comparative importance of fire danger rating indices and their integration with spatial and temporal variables for predicting daily human-caused fire occurrences in Spain. International Journal of Wildland Fire, 20(1): 46-58.

RATKNIĆ, T. M., RATKNIĆ, M. B., RAKONJAC, N. L., ŽIVANOVIĆ, I. M. and PODUŠKA, Z. B. 2019. Development of a national index for the purpose of forest fire risk assessments on the example of southern Serbia. Thermal Science, online first only: doi.org/10.2298/TSCI190412276R.

ROADS, J. A., FUJIOKA, B., CHEN, S. B. and BURGAN, R. C. 2005. Seasonal fire danger forecasts for the USA. International Journal of Wildland Fire, 14: 1-18.

TANSKANEN, H., VENÄLÄINEN, A., PUTTONEN, P. and GRANSTRÖM, A. 2005. Impact of stand structure on surface fire ignition potential in Picea abies and Pinus sylvestris forests in southern Finland. Canadian Journal of Forest Research, 35(2): 410-420.

TRNKA, M., SEMERÁDOVÁ, D., NOVOTNÝ, I., DUMBROVSKÝ, M., DRBAL, K. et al. 2016. Assessing the combined hazards of drought, soil erosion and local flooding on agricultural land: a Czech case study. Climate Research, 70(2-3): 231-249.

VAJDA, A., VENÄLÄINEN, A., SUOMI, I., JUNILA, P. and MÄKELÄ, H. M. 2014. Assessment of forest fire danger in a boreal forest environment: Description and evaluation of the operational system applied in Finland. Meteorological Applications, 21(4): 879-887.

VAN WAGNER, C. E. 1974. Structure of the Canadian Forest Fire Weather Index. Publication No. 1333. Ottawa, ON: Canadian Forestry Service.

WOTTON, B. M. 2009. Interpreting and using outputs from the Canadian Forest Fire Danger Rating System in research applications. Environmental and Ecological Statistics, 16(2): 107-131. 